\title{
Fulvivirga imtechensis sp. nov., a member of the phylum Bacteroidetes
}

\author{
Nupur, Shalley Sharma, Pradip Kumar Singh, Korpole Suresh \\ and Pinnaka Anil Kumar
}

Correspondence

Pinnaka Anil Kumar apinnaka@imtech.res.in

\author{
Microbial Type Culture Collection and Gene Bank, Institute of Microbial Technology (CSIR), \\ Sector 39A, Chandigarh - 160 036, India
}

\begin{abstract}
A novel, Gram-staining-negative, yellow-coloured, rod-shaped, obligately aerobic, non-motile bacterium, designated strain $A K 7^{\top}$, was isolated from seawater collected on the coast at Visakhapatnam, Andhra Pradesh, India. The predominant fatty acids of the novel strain were iso$\mathrm{C}_{15: 0}$, iso- $\mathrm{C}_{15: 0} 3-\mathrm{OH}, \mathrm{C}_{16: 1} \omega 5 c$, iso- $\mathrm{C}_{17: 0} 3-\mathrm{OH}$ and summed features $3\left(\mathrm{C}_{16: 1} \omega 7 \mathrm{c}\right.$ and/or iso- $\mathrm{C}_{15: 0} 2-\mathrm{OH}$ ) and 4 (iso- $\mathrm{C}_{17: 1} \mathrm{I}$ and/or anteiso- $\mathrm{C}_{17: 1} \mathrm{~B}$ ). The major respiratory quinone was MK-7 and the polar lipid profile comprised phosphatidylethanolamine, two unidentified aminolipids and four other unidentified lipids. In phylogenetic analysis based on 16S rRNA gene sequences, strain $A K 7^{\top}$ appeared most closely related to Fulvivirga kasyanovii KMM $6220^{\top}$ (95.9\% sequence similarity), a member of the family Flammeovirgaceae in the phylum Bacteroidetes. The genomic DNA G $+C$ content of strain $A K 7^{\top}$ was $55.1 \mathrm{~mol} \%$. Based on the morphological, biochemical, physiological, chemotaxonomic and phylogenetic evidence, strain $\mathrm{AK} 7^{\top}$ represents a novel species of the genus Fulvivirga for which the name Fulvivirga imtechensis sp. nov. is proposed. The type strain is $A K 7^{\top}\left(=\operatorname{MTCC} 11053^{\top}=J C M 17390^{\top}\right)$.
\end{abstract}

The genus Fulvivirga, which was described by Nedashkovskaya et al. (2007), lies within the family Flammeovirgaceae of the phylum Bacteroidetes. Members of the phylum Bacteroidetes are very diverse and, although most have been isolated from marine and freshwater habitats (O'Sullivan et al., 2006), some have been isolated from soil, plants or the air (Buczolits et al., 2002). At the time of writing, the genus Fulvivirga comprised only one species, Fulvivirga kasyanovii, which was initially isolated from seawater (Nedashkovskaya et al., 2007). The aim of the present study was to a use a polyphasic approach to determine the taxonomic position of a Fulvivirga-like bacterium that was recently isolated from seawater collected on the coast of south-eastern India.

Surface seawater (at $\mathrm{pH} 7.5$ and $30{ }^{\circ} \mathrm{C}$, with a salinity of 33 p.p.m.) was collected from the coast at Visakhapatnam, Andhra Pradesh, India. A sample of the water $(1 \mathrm{ml})$ was serially diluted in saline $[2 \%(\mathrm{w} / \mathrm{v}) \mathrm{NaCl}]$ before $100 \mu \mathrm{l}$ of each dilution was plated on ZoBell's marine agar (ZMA; Difco) and incubated at $30{ }^{\circ} \mathrm{C}$. A yellowish colony was observed after 7 days of incubation; cells were purified, designated strain $A K 7^{\mathrm{T}}$, and preserved in $20 \%(\mathrm{v} / \mathrm{v})$ glycerol at $-70{ }^{\circ} \mathrm{C}$.

The cell morphology of the novel strain was studied by phase-contrast microscopy (BX 51; Olympus). Gram staining was determined using a Gram staining kit (HiMedia)

The GenBank/EMBL/DDBJ accession number for the 16S rRNA gene sequence of strain $A K 7^{\top}$ is FR687203. according to the manufacturer's instructions. The strain was incubated on ZMA at 4, 10, 15, 20, 25, 30, 35, 37, 40 and $45{ }^{\circ} \mathrm{C}$ to determine the growth temperature. $\mathrm{NaCl}$ tolerance was determined at $30^{\circ} \mathrm{C}$ and $\mathrm{pH} 7.5$ on nutrient agar (NA) containing $\left(1^{-1}\right) 5 \mathrm{~g}$ peptone, $3 \mathrm{~g}$ beef extract and $20 \mathrm{~g}$ agar, with $1,2,3,4,5,6,8,10,12,15,18$ or $20 \%(w / v) ~ \mathrm{NaCl}$. Growth at various $\mathrm{pH}$ values was assessed on tryptic soy agar (TSA; Difco) buffered with citric acid/ $\mathrm{NaOH}$ (to give $\mathrm{pH} 5.0$ and 6.0), $\mathrm{NaHPO}_{4} / \mathrm{Na}_{2} \mathrm{HPO}_{4}(\mathrm{pH} 7.0,7.5,8.0$ and 8.5), glycine/ $\mathrm{NaOH}(\mathrm{pH} 9.0,9.5$ and 10.0$)$ or Tris/ $\mathrm{HCl}$ or $\mathrm{NaOH}$ $\left(\mathrm{pH} 11.0\right.$ and 12.0). The ability of strain $\mathrm{AK} 7^{\mathrm{T}}$ to utilize various compounds as sole carbon sources (at $25 \mathrm{mg}$ ) was checked on minimal medium (Cowan \& Steel, 1965) supplemented with $2 \%(\mathrm{w} / \mathrm{v}) \mathrm{NaCl}$. Biochemical and enzymic characterization of the strain $\mathrm{AK}^{\mathrm{T}}$ was performed using Vitek 2 colorimetric GN cards (bioMérieux), at $30{ }^{\circ} \mathrm{C}$ and according to the manufacturer's instructions, except that sterile $2.0 \%(\mathrm{w} / \mathrm{v}) \mathrm{NaCl}$ was used to prepare the inoculum.

For analysis of fatty acids and polar lipids, cell biomass of the novel strain and, for comparison, Fulvivirga kasyanovii JCM $16186^{\mathrm{T}}$ was produced by aerobic culture for $24 \mathrm{~h}$ on ZMA at $30{ }^{\circ} \mathrm{C}$. Fatty acid methyl esters were prepared and analysed by following the protocol of version 4.0 of the Sherlock Microbial Identification System (MIDI) and using the TSBA50 peak-naming database. Polar lipids were extracted and separated, by two-dimensional TLC, as described by Collins \& Jones (1980). Molybdatophosphoric acid, molybdenum blue, ninhydrin and $\alpha$-naphthol spray 


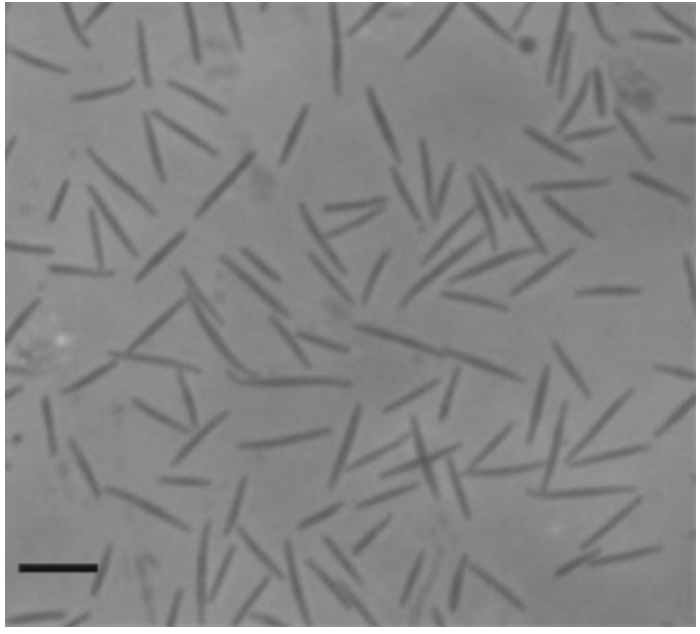

Fig. 1. Phase-contrast micrograph of cells of strain $A K 7^{\top}$. Bar, $5 \mu \mathrm{m}$.

reagents were then used for the detection of total lipids, phospholipids, aminolipids and glycolipids on the TLC plates, respectively. Isoprenoid quinones were extracted as described by Collins et al. (1977) and analysed by HPLC (Groth et al., 1996). Genomic DNA was extracted and purified according to the method of Marmur (1961) so that its $\mathrm{G}+\mathrm{C}$ content could be determined, by the melting-point method (Sly et al., 1986), in a Lambda 35 spectrophotometer (Perkin Elmer).

For the phylogenetic analysis, DNA was extracted from the novel strain and purified by using a genomic DNA extraction kit (Qiagen). The 16S rRNA gene was then amplified by PCR, using the universal bacterial primers $27 f\left(5^{\prime}-A G-\right.$ AGTTTGATCCTGGCTCAG-3') and 1492r ( $5^{\prime}$-TACGGYTACCTTGTTACGACTT-3'). After the amplicon was purified, using a QIA quick PCR purification kit (Qiagen), it was sequenced in an ABI Prism 3700 automatic DNA sequencer (Applied Biosystems) by the use of a BigDye Terminator Cycle Sequencing kit (Applied Biosystems). Phylogenetic neighbours were identified and pairwise 16S rRNA gene sequence similarities were calculated using a BLAST sequence similarity search (Altschul et al., 1990) and the EzTaxon server (Chun et al., 2007). 16S rRNA gene sequences that were similar to that of $A K 7^{\mathrm{T}}$ were downloaded from the database of the United States National Center for Biotechnology Information (http://www.ncbi.nlm.nih.gov) so that they could be aligned, along with the sequence of the novel strain, using CLUSTAL W (Thompson et al., 1994) within version 5 of the MEGA package (Tamura et al., 2011). The alignment was then corrected manually with the BioEdit sequence alignment editor (Hall, 1999). Phylogenetic trees were constructed, using both the maximum-likelihood and neighbour-joining algorithms, again using the MEGA package, with evolutionary distances calculated in the Kimura two-parameter model and the tree topologies evaluated by bootstrap analyses with 1000 replications.

The cells of strain $A K 7^{\mathrm{T}}$ were non-motile rods (Fig. 1). The predominant fatty acid was iso- $\mathrm{C}_{15: 0}$ and the major respiratory quinone was $\mathrm{MK}-7$. The polar lipid profile (Fig. 2) comprised phosphatidylethanolamine, two unidentified aminolipids and four other unidentified lipids. The genomic DNA G+C content was $55.1 \pm 0.06$ mol\%. Further details and other characteristics of the novel strain are given in the species description.

In the phylogenetic analysis based on 16S rRNA gene sequences, strain $\mathrm{AK}^{\mathrm{T}}$ appeared to be most closely related to F. kasyanovii KMM $6220^{\mathrm{T}}$ (95.9\% sequence similarity) and clustered with this type strain in both the maximumlikelihood and neighbour-joining trees (Fig. 3). However, strain $A K 7^{\mathrm{T}}$ could be distinguished from $F$. kasyanovii JCM $16186^{\mathrm{T}}$ by its cell size, $\mathrm{NaCl}$ requirement and tolerance, temperature range for growth, fatty acid and polar lipid
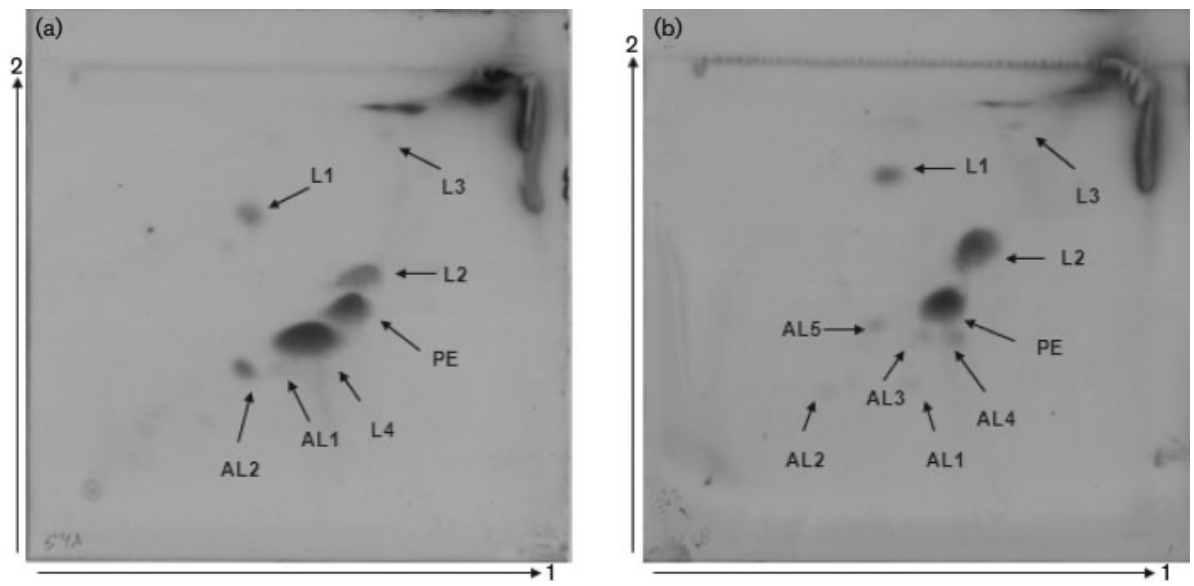

Fig. 2. Two-dimensional TLCs of the polar lipids of strain $A K 7^{\top}$ (a) and Fulvivirga kasyanovii JCM $16186^{\top}$ (b), after staining with molybdatophosphoric acid. PE, phosphatidylethanolamine; AL1-AL5, unidentified aminolipids; L1-L4, unidentified lipids. Directions of first and second dimensions are indicated. 

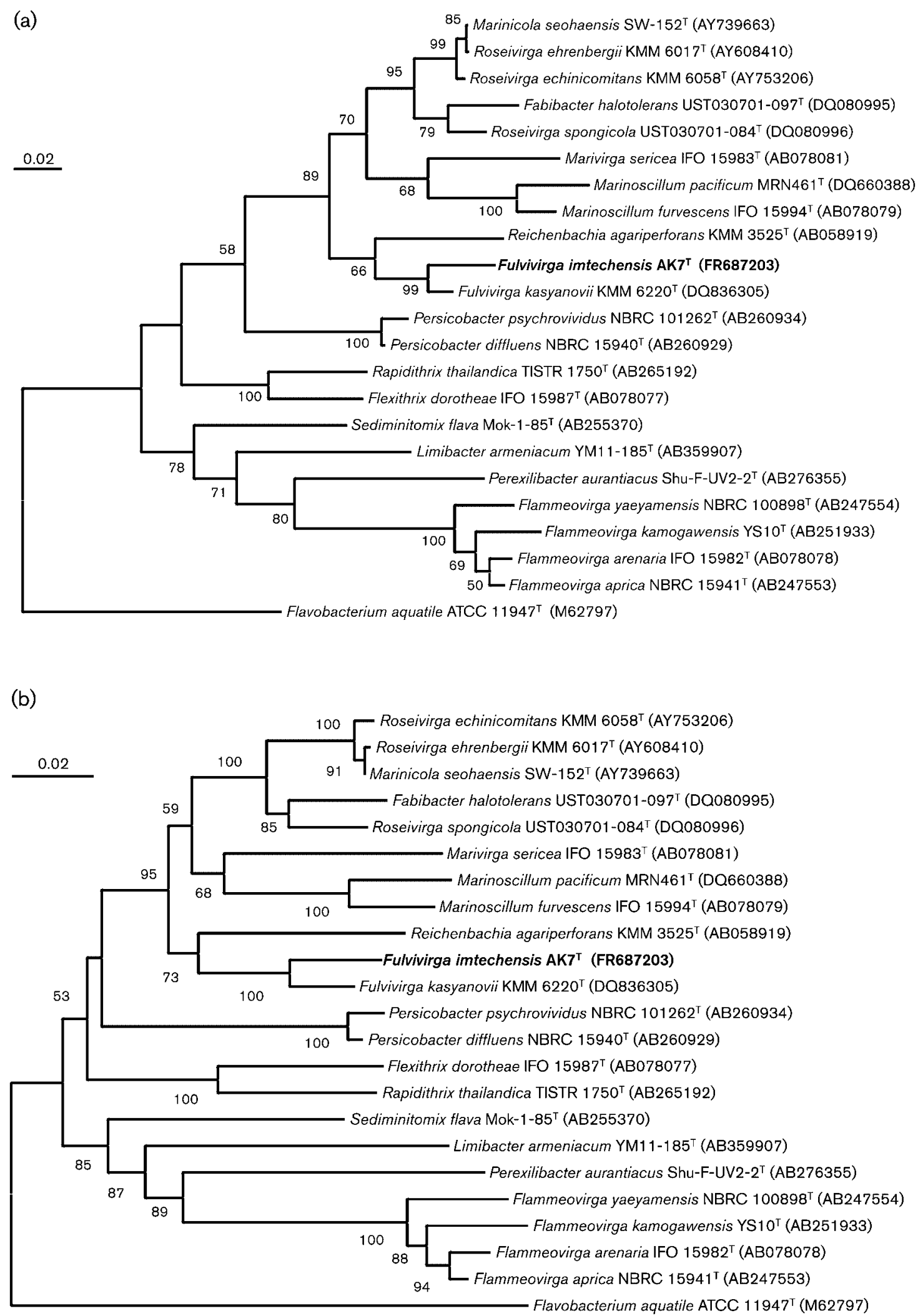

Fig. 3. Maximum-likelihood (a) and neighbour-joining (b) phylogenetic trees based on 16S rRNA gene sequences, showing the relationship between strain $A K 7^{\top}$ and members of the family Flammeovirgaceae. Bootstrap values $\geqslant 50 \%$ (based on 1000 replications) are given at branch points. Flavobacterium aquatile ATCC $11947^{\top}$ was used as an outgroup. Bars, 0.02 substitutions per nucleotide position. 
profiles and genomic DNA G $+\mathrm{C}$ content (Tables 1 and 2). Based on the phenotypic, chemotaxonomic and phylogenetic evidence, strain $A K 7^{\mathrm{T}}$ represents a novel species of the genus Fulvivirga for which the name Fulvivirga imtechensis sp. nov. is proposed.

\section{Description of Fulvivirga imtechensis sp. nov.}

Fulvivirga imtechensis (im.tech.en'sis. N.L. fem. adj. imtechensis an arbitrary adjective formed from IMTECH, the acronym of the Institute of Microbial Technology in Chandigarh, where the isolate was characterised).

Cells are Gram-staining-negative, non-spore-forming, nonmotile rods $(0.3-0.5 \times 5-6 \mu \mathrm{m})$ that multiply by binary fission. Colonies on ZMA are circular, 1-2 $\mathrm{mm}$ in diameter, smooth, yellowish in colour, translucent and raised. Grows well at $30-37{ }^{\circ} \mathrm{C}$ and at $\mathrm{pH} 7.0-8.0$. Growth occurs with $2-$ $12 \%(\mathrm{w} / \mathrm{v}) \mathrm{NaCl}$ (optimum between $2 \%$ and $6 \%$ ). Positive for aesculin hydrolysis, oxidase and catalase activities, and nitrate reduction but negative for DNase, urease, amylase and caseinase activities, indole production and hydrolysis of Tweens 20, 40, 60 and 80. Utilizes maltose, D-mannose, sucrose, trehalose, galactose, xylose, cellobiose and fructose but not D-sorbitol, melibiose, D-lactose, dulcitol, salicin, raffinose, L-rhamnose, inulin or inositol. Positive (on Vitek 2 GN cards) for Ala-Phe-Pro arylamidase, adonitol, glutamyl arylamidase-p-nitroanilide, L-proline arylamidase and tyrosine arylamidase activities but negative for citrate utilization and $N$-acetyl- $\beta$-glucosaminidase, $N$-acetyl- $\beta$-galactosaminidase, phosphatase, lysine decarboxylase, ornithine decarboxylase, $\beta$-glucosidase, $\beta$-xylosidase, glycine arylamidase, Glu-Gly-Arg arylamidase, galactosidase, $\alpha$-glucosidase,

Table 1. Characteristics that distinguish strain $A K 7^{\top}$ from Fulvivirga kasyanovii JCM $16186^{\top}$

Strains: 1, AK7 ${ }^{\mathrm{T}} ; 2$, F. kasyanovii JCM $16186^{\mathrm{T}}$. Both strains are positive for Ala-Phe-Pro arylamidase, glutamyl arylamidase- $p$ - nitroanilide, L-proline arylamidase, tyrosine arylamidase, oxidase, catalase and urease activities, growth on MacConkey agar and citrate utilization. Both are negative for Gram staining, indole production, alkalinization of L-lactate and succinate, acidification of L-arabitol, cellobiose, coumarate, D-glucose, maltose, Dmannitol, D-mannose, palatinose, D-sorbitol, sucrose, D-tagatose, trehalose, malonate and 5-keto-D-gluconate, assimilation of trisodium citrate, Lhistidine, L-malate and L-lactate, glucose fermentation, and $\beta$-galactosidase, $N$-acetyl- $\beta$-glucosaminidase, $\gamma$-glutamyl transferase, $\beta$-glucosidase, $\beta$-xylosidase, $\beta$-alanine arylamidase- $p$-NA, lipase, urease, $\alpha$-glucosidase, $N$-acetyl- $\beta$-galactosaminidase, galactosidase, glycine arylamidase, ornithine decarboxylase, lysine decarboxylase and $\beta$-glucuronidase activities. +, Positive; -, negative; PE, phosphatidylethanolamine; AL1-AL5, unidentified aminolipids; L1-L4, unidentified lipids.

\begin{tabular}{|c|c|c|}
\hline Characteristic & 1 & 2 \\
\hline Cell shape & Rod & Rod \\
\hline Cell width $(\mu \mathrm{m})$ & $0.3-0.5$ & $0.2-0.3$ \\
\hline Cell length $(\mu \mathrm{m})$ & $5-6$ & $2.3-2.5$ \\
\hline Motility & - & + \\
\hline \multicolumn{3}{|l|}{$\mathrm{NaCl}$ concentration for growth $(\%, w / v)$} \\
\hline Range & $0-15$ & $0-10$ \\
\hline Optimum & $2-6$ & $2-3$ \\
\hline \multicolumn{3}{|l|}{ Growth temperature $\left({ }^{\circ} \mathrm{C}\right)$} \\
\hline Range & $20-40$ & $15-45$ \\
\hline Optimum & $30-35$ & $35-37$ \\
\hline Optimum $\mathrm{pH}$ for growth & $7-8$ & $7.5-8.0$ \\
\hline Growth on TSA & - & + \\
\hline \multicolumn{3}{|l|}{ Hydrolysis of: } \\
\hline Tween 40 & - & + \\
\hline Tween 80 & - & + \\
\hline Aesculin & + & - \\
\hline Nitrate reduction & + & - \\
\hline \multicolumn{3}{|l|}{ Activity of: } \\
\hline DNase & - & + \\
\hline Gelatinase & - & + \\
\hline Caseinase & - & + \\
\hline L-Pyrrolydonyl arylamidase & - & + \\
\hline Phosphatase & - & + \\
\hline Glu-Gly-Arg arylamidase & - & + \\
\hline Adonitol acidification & + & - \\
\hline Quinone & MK-7 & MK-7 \\
\hline Polar lipids & PE, AL1, AL2, L1-L4 & PE, AL1-AL5, L1-L3 \\
\hline Genomic DNA G + C content $(\mathrm{mol} \%)$ & 55.1 & 60.7 \\
\hline
\end{tabular}


Table 2. Cellular fatty acid contents (\%) of strain $A K 7^{\top}$ and Fulvivirga kasyanovii JCM $16186^{\top}$

Strains: $1, \mathrm{AK}^{\mathrm{T}} ; 2$, F. kasyanovii JCM $16186^{\mathrm{T}}$. All data are from the present study. - , Not detected.

\begin{tabular}{|lcc|}
\hline Fatty acid & $\mathbf{1}$ & $\mathbf{2}$ \\
\hline iso- $\mathrm{C}_{13: 0}$ & - & 0.36 \\
$\mathrm{C}_{14: 0}$ & 0.61 & 0.48 \\
iso- $_{15: 1} \mathrm{G}$ & 4.10 & 5.50 \\
iso- $_{15: 0}$ & 54.61 & 56.39 \\
anteiso-C $_{15: 0}$ & 1.19 & 1.71 \\
$\mathrm{C}_{16: 1} \omega 5 c$ & 14.35 & 7.57 \\
iso- $_{15: 0} 3-\mathrm{OH}$ & 5.11 & 8.43 \\
$\mathrm{C}_{16: 0}$ & 1.03 & - \\
$\mathrm{C}_{16: 0} 3-\mathrm{OH}$ & - & 0.69 \\
iso- & 9.87 & 11.56 \\
Summed features & & \\
3 & 3.93 & 3.53 \\
4 & 3.94 & 1.16 \\
\hline
\end{tabular}

${ }^{\star}$ Summed features represent groups of two fatty acids that could not be separated by GLC with the MIDI system. Summed feature 3 contained $\mathrm{C}_{16: 1} \omega 7 c$ and/or iso- $\mathrm{C}_{15: 0}$ 2-OH. Summed feature 4 contained iso- $\mathrm{C}_{17: 1} \mathrm{I}$ and/or anteiso- $\mathrm{C}_{17: 1} \mathrm{~B}$.

lipase, palatinose, $\beta$-alanine arylamidase- $p$ - nitroanilide and $\gamma$-glutamyl transferase activities. Fatty acid profile is dominated by iso- $\mathrm{C}_{15: 0}$, iso- $\mathrm{C}_{15: 0} 3-\mathrm{OH}, \mathrm{C}_{16: 1} \omega 5 c$, iso- $\mathrm{C}_{17: 0} 3-$ $\mathrm{OH}$, summed feature $3\left(\mathrm{C}_{16: 1} \omega 7 c\right.$ and/or iso- $\left.\mathrm{C}_{15: 0} 2-\mathrm{OH}\right)$ and summed feature 4 (iso- $\mathrm{C}_{17: 1} \mathrm{I}$ and/or anteiso- $\mathrm{C}_{17: 1} \mathrm{~B}$ ). The major isoprenoid quinone is MK-7. The polar lipid profile comprises phosphatidylethanolamine, two unidentified aminolipids and four other unidentified lipids.

The type strain, $\mathrm{AK} 7^{\mathrm{T}}\left(=\mathrm{MTCC} 11053^{\mathrm{T}}=\mathrm{JCM} 17390^{\mathrm{T}}\right)$, was isolated from seawater collected on the coast at Visakhapatnam, Andhra Pradesh, India. The genomic DNA G $+\mathrm{C}$ content of the type strain is $55.1 \pm 0.06 \mathrm{~mol} \%$.

\section{Acknowledgements}

The authors thank Dr J. Euzéby, for his expert suggestion for the correct species epithet and Latin etymology, and Mr Deepak Bhatt, for his excellent help in the DNA sequencing. They are also grateful to the Indian Council of Scientific and Industrial Research (CSIR) and Department of Biotechnology, Government of India, for financial assistance.

\section{References}

Altschul, S. F., Gish, W., Miller, W., Myers, E. W. \& Lipman, D. J. (1990). Basic local alignment search tool. J Mol Biol 215, 403-410.

Buczolits, S., Denner, E. B. M., Vybiral, D., Wieser, M., Kämpfer, P. \& Busse, H.-J. (2002). Classification of three airborne bacteria and proposal of Hymenobacter aerophilus sp. nov. Int J Syst Evol Microbiol 52, 445-456.

Chun, J., Lee, J.-H., Jung, Y., Kim, M., Kim, S., Kim, B. K. \& Lim, Y. W. (2007). EzTaxon: a web-based tool for the identification of prokaryotes based on 16S ribosomal RNA gene sequences. Int J Syst Evol Microbiol 57, 2259-2261.

Collins, M. D. \& Jones, D. (1980). Lipids in the classification and identification of coryneform bacteria containing peptidoglycans based on 2,4-diaminobutyric acid. J Appl Bacteriol 48, 459-470.

Collins, M. D., Pirouz, T., Goodfellow, M. \& Minnikin, D. E. (1977). Distribution of menaquinones in actinomycetes and corynebacteria. J Gen Microbiol 100, 221-230.

Cowan, S. T \& Steel, K. J. (1965). Manual for the Identification of Medical Bactria. London: Cambridge University Press.

Groth, I., Schumann, P., Weiss, N., Martin, K. \& Rainey, F. A. (1996). Agrococcus jenensis gen. nov., sp. nov., a new genus of actinomycetes with diaminobutyric acid in the cell wall. Int J Syst Bacteriol 46, 234239.

Hall, T. A. (1999). BioEdit: a user-friendly biological sequence alignment editor and analysis program for Windows 95/98/NT. Nucleic Acids Symp Ser 41, 95-98.

Marmur, J. (1961). A procedure for the isolation of deoxyribonucleic acid from microorganisms. J Mol Biol 3, 208-218.

Nedashkovskaya, O. I., Kim, S. B., Shin, D. S., Beleneva, I. A. \& Mikhailov, V. V. (2007). Fulvivirga kasyanovii gen. nov., sp. nov., a novel member of the phylum Bacteroidetes isolated from seawater in a mussel farm. Int J Syst Evol Microbiol 57, 1046-1049.

O’Sullivan, L. A., Rinna, J., Humphreys, G., Weightman, A. J. \& Fry, J. C. (2006). Culturable phylogenetic diversity of the phylum 'Bacteroidetes' from river epilithon and coastal water and description of novel members of the family Flavobacteriaceae: Epilithonimonas tenax gen. nov., sp. nov. and Persicivirga xylanidelens gen. nov., sp. nov. Int J Syst Evol Microbiol 56, 169-180.

Sly, L. I., Blackall, L. L., Kraat, P. C., Tian-Shen, T. \& Sangkhobol, V. (1986). The use of second derivative plots for the determination of mol\% guanine plus cytosine of DNA by the thermal denaturation method. J Microbiol Methods 5, 139-156.

Tamura, K., Peterson, D., Peterson, N., Stecher, G., Nei, M. \& Kumar, S. (2011). MEGA5: molecular evolutionary genetics analysis using maximum likelihood, evolutionary distance, and maximum parsimony methods. Mol Biol Evol 28, 2731-2739.

Thompson, J. D., Higgins, D. G. \& Gibson, T. J. (1994). CLUSTAL W: improving the sensitivity of progressive multiple sequence alignment through sequence weighting, position-specific gap penalties and weight matrix choice. Nucleic Acids Res 22, 4673-4680. 